\author{
Chapter 12 \\ THE BEACH EROSION BOARD: \\ Dabney O. Elliott \\ President, Beach Erosion Board \\ Department of the Army \\ Washington, D C.
}

\begin{abstract}
INTRODUCTION
The purpose of this paper is to describe the methods by which, and the extent to which the Federal Government participates with local agencies in the control of beach erosion. The Beach Erosion Board of the Corps of Engineers is the instrumentality through which this participation is effected. However, before describing this Board, it is necessary to sketch very briefly the background of the beach erosion problem as viewed from the national standpoint.
\end{abstract}

The necessity for the control of beach erosion by one means or another has no doubt been recognized from the beginning of the practice of coastal engineering in the United States. The early technical records of the Corps of Engineers contain numerous references to the mutual effects whIch navigation structures and the adjacent shorelines exert upon each other. As an example, chosen at random, I may mention the construction in 1874 of twelve stone groins along the shore of the State of Connecticut between Welshs Point and Indian RIver, and of a stone jetty at the mouth of that river in the following year, to stabilize the shoreline and to prevent the movement of sand into the navigation channel of that river.

Interest in the related phenomena of wave action, tidal currents, and beach erosion increased materially after the turn of the century, as witness the contemporary professional writings of well known officers of the Corps of Engineers. Noteworthy among these was the report of Captain D. D. Gaillard on "Wave Action in Relation to Engineering Structures" published in 1904. Individual beach erosion problems were studied in the Engineer Districts and boards were occasionally convened by the Chief of Engineers to consider important or critical cases. However, during the first quarter of the present century the approach to the general problem of beach erosion was primarily through individual case studies. The attack was therefore piecemeal in character. The organization by the chief of Engineers of the "Board on Sand Movement and Beach Erosion" in January 1929 appears to have been the first attempt by the Federal Government to approach the problem on a comprehensive scale. Th1s Board had a short life, being superseded in 1930 by the Beach Erosión Board.

Meanwhile, the State of New Jersey had been seriously concerned with the damaging erosion which was then occurring along the major portion of its ocean front shoreline. In the early twenties the State Board of Commerce and Navigation succeeded in obtaining from the Legislature the necessary authorization to undertake studies with a view to developing means of protection. A State Engineering Advisory Board thereupon was created for the purpose. This Board followed the pattern established by the British Royal Commission (1906-1911), 1.e., to use the coast itself as a laboratory and, by the analyses of observed phenomena, to deduce methods of erosion control. Thus, New Jersey was the first state in the Union to enter the fleld of shore protection and beach erosion control. The close similarity between the New Jersey State Engineering Advisory Board and the Beach Erosion Board, leads to the deduction that the former board served as a model for the organization of the latter one.

\title{
THE BEACH EROSION BOARD
}

The fundamental law establishing the Beach Erosion Board is dated July 3, 1930. This law accomplished two principal objectives. First, it created the Board and defined its duties; and second, it established the procedure by which cooperative

*The opinions expressed in this paper are those of the writer and do not necessarily represent the views of the Chief of Engineers or of the Department of the Army. 
beach erosion studies and reports are made. These reports are made by the corps of Engineers, as the agent of the Federal Government, at the behest of local political subdivisions (state, county, or municipality), the cost being borne equally by the two cooperating agencies. They will be discussed in some detail later.

The scope of the Beach Erosion Board's activities was at first restricted largely to the preparation and review of cooperative reports, and so continued unt1l the end of World War II. Post-war legislation has, however broadened very materially the Board's powers and responsibilities. In 1945 legislation was enacted authorizing the Board to undertake a program of general investigation and research, and to publish technical information relating to the problem of beach erosion and its control. In the following year, the principle of Federal cooperation in beach erosion control was established by a law authorizing the Federal Government to participate in the cost of construction of works designed to protect the shores of publicly owned (non-Federal) property. The protection of federal shore property is of course exclusively a Federal responsibility.

In this connection, it is of interest to mention that, in 1935, legislation was enacted which recognizes the obvious relationship which exists between seacoast navigation structures and adjacent shoreline processes. This legislation requires that reports on proposed navigation improvements at the mouths of rivers, or at entrances to inlets consider the probable effects which these improvements will have upon the adjacent shores.

The time element in this summary of our national legislation is significant. The Board was created in 1930 and at the same time the principle of Federal participation in beach erosion control studies was established. It was, however, fifteen years later that the Board was authorized to undertake the essential function of research and another year elapsed before the principle of Federal assistance in the cost of protective construction was established.

\section{ORGANIZATION AND DUTIES OF THE BOARD}

The Beach Erosion Board consists of seven members appointed by the Chlef of Engineers. Four are officens of the Corps of Engineers, the senior one of whom is the President and Resident Member of the Board. The remaining three members are civilians selected with regard to their special fitness from among the engineers of state agencies cooperating with the Department of the Army in beach erosion control. These civilians serve without remuneration by the United States although they are reimbursed for travel and personal expenses incurred while on Board duty. The office of the Board is located in Washington, D.C. A small board staff operates under the direct supervision of the President. Although not specifically required by law, an additional Engineer officer serves as Executive officer of the Office.

The duties of the Board, as fixed by law, are as follows:

a. To furnish technical assistance in the conduct of beach erosion control studies;

b. To review the reports of these studies;

c. To make inspections and examinations as necessary of localities under study;

d. To conduct general investigations and research;

e. To publish from time to time useful data and information concerning beach erosion and its control.

In reviewing a beach erosion control report, the Board is required to state its opinion as to:
a. The advisability of adopting the proposed beach erosion control project;
b. The public interest (if any) involved in the proposed improvement;
c. What share (if any) of the cost should be borne by the United states. 
Since the Board does not remain continuously in Washington, D.C., its routine duties and responslbilities are discharged very largely through the instrumentality of the President and Board staff. The review of cooperative reports and the determination of the advisability of recommended beach erosion control projects (including the share of the cost recommended to be borne by the United states) are, however, duties which the Board habitually performs in board session. These responsibilities are never delegated to any individual.

Board meetings average five or six a year. When assembled for these meetings the Board normally inspects as a body some critical or important reach of shoreline of current interest. As a result Board meetings are more frequently held in coastal cities than in Washington, D.C. In addition to these inspections, individual members make inspections as opportunity and time permit. By this practice the Board is able to keep currently posted as to major beach erosion problems.

\section{COOPERATIVE BEACH EROSION CONTROL REPORTS}

As stated above, cooperative reports are made by the Corps of Engineers at the request of local political subdivisions (States, Counties, or Municipalities). The costs are borne equally by the United States and the local cooperating agencies. The objectives of a cooperative report are normally to ascertain the causes and extent of beach erosion along a specific reach of shoreline, and to determine the most feasible plan for improving and protecting it against further attack. It is important to differentiate between this type of report and the so-called preliminary examinations and survey reports of the Corps of Engineers. These 1atter reports are made in response to Congressional directives. Cooperative reports on the other hand are made at the instance of local govermmental agencies. Specific congressional authority is not required. When completed they are the joint property of the United States and of the cooperating State, County, or Municipality. The desires of the local agency must obviously be kept in mind while the reports are being prepared.

The procedure followed in the preparation of a cooperative report is a fairly simple one. The local governmental agency desiring the report first contacts the local District Engineer (of the Corps of Engineers). The latter prepares a preliminary analysis of the problem, a proposed program of field work, and an estimate of cost. These are forwarded to the office of the Beach Erosion Board for comment. Representatives of this office then visit the field, inspect the reach of shoreline to be studied, and reach agreements with the District Engineer and the local cooperating agency as to the program to be followed and the estimated cost. When these details have been settled, the local govermmental agency submits a formal letter of application for the cooperative study. On approval by the chief of Engineers this application becomes the contract covering the work. The local District Engineer then proceeds with the field work. The contribution by the local cooperating agency may be elther in cash or in the form of services performed in connection with the study.

The completed report contains an analysis of the causes of erosion, and presents a recommended plan of improvement and protection. The report also contains conclusions as to the economic feasibility of the project as a whole and as to the amount of public interest and the amount (if any) of the recommended Federal contribution toward the cost of the project. This report is forwarded through channels to the Chief of Engineers who in turn refers it to the Beach Erosion Board for review. After review by the Board, the report is referred to the Bureau of the Budget for a finding as to whether the proposed work should be included in the current national construction program. Thereafter, it is forwarded by the Secretary of the Army to congress. If the report is approved by the congress, the project is included as an item in an authorization act. Thereafter funds must be appropriated before Federal assistance can become a fact.

Several points are noteworthy in connection with this procedure. A public notice is issued by the Division Engineer as soon as practicable after the report has been completed by the District Engineer. This notice briefly describes the proposed plan of protection including the cost and the recommended amount of the Federal contribution thereto. Interested parties are thus given an opportunity to 
forward their.comments to the Beach Erosion Board for consideration prior to the completion of Board action on the report. If the comments are sufficiently important, the Board may hold a public hearing prior to completing action. In practice, however, comments in response to public notices are not numerous and public hearings have almost never been necessary up to the present time. The reason lies in the fact that the District Engineer and the cooperating agency keep in close contact during the preparation of the report. Comments are therefore usually made while the plan is in its formative stage and can therefore be disposed of before the report reaches the Board.

Federal participation in the cost of protection is by law restricted to public property. Nevertheless cooperative reports always cover the protection of such privately owned shores as may be within the limits of the study areas, and normally include proposed plans for the protection of these shores even though Federal funds cannot be applied toward the construction of the proposed structures. In fact, instances frequently occur in which the aggregate length of privately owned shoreline under study considerably exceeds that of the publicly owned shoreline. This is typical of the states of Ohio and Connecticut where progressive cooperative studies are now under way which will ultimately cover the entire shorelines of these two states.

It is to be noted here that the law does not permit private individuals to apply for cooperative reports even though they are willing and able to meet the local share of the cost. Applications must originate with political subdivisions (normally the State, the County, or Municipality).

\section{FEDERAL PARTICIPATION IN COST}

The legislation which authorized Federal participation in the cost of shore protection (Public Law 727, Seventy-Ninth Congress) was passed in 1946 . This law states that "with the purpose of preventing damage to public property and promoting and encouraging the healthful recreation of the people," the United States w111 "assist in the construction, but not the maintenance, of works for the improvement and protection against erosion" of the shores of the United States which are owned by states, Municipalities, or other political subdivisions, provided the Federal contribution to the cost of construction of protective works does not exceed one-third of the total cost. This law, therefore, provides for Federal assistance but limits it to publicly owned property. It recognizes the element of improvement, as well as protection, and lastly, it establishes public recreation as a legitimate objective. The maximum amount of Federal participation is fixed, but within that maximum the actual Federal contribution in any individual case is discretionary.

Since the passage of this Act, five projects involving Federal assistance have been authorized by the congress but as yet no funds for this assistance have been appropriated. Fifteen additional cooperative reports, including five now before the Board, have been completed and will probably result in additional congressional authorizations during the coming year. However, the number of projects fully processed to date is too small to indicate with certainty the working limits of pollcy which will in the future govern the amount of Federal assistance in individual cases. The following considerations in this connection represent the personal views of the writer. They are not to be interpreted as representative of Board policy.

It is seemingly axiomatic that Federal assistance in any beach erosion control project must rest on two fundamental conditions, 1.e., substantial public interest and economic soundness. The term "interest" is used here to connote a real public advantage and not merely a favorable opinion. Economic soundness is obviously a prerequisite to Federal aid. Projects which do not meet these two fundamental requirements should not be consldered as eliglble for Federal assistance.

In many cases, the substantial public interest mentioned above will consist predominantly of recreational features although not necessarily confined thereto. A shore protection project may well be intended solely to prevent erosion damage to valuable public shore front property and may contain no element either of improvement or of public recreation. Such a project should not be denied Federal 


\section{COASTAL ENGINEERING}

aid merely because recreational benefits do not exist. Moreover, when these recreational benefits do exist, they should be substantial, reasonably certain to develop, and should accrue to the general public. Recreational benefits which can be enjoyed only by small groups of fortunately situated property owners do not, in the opinion of the writer, warrant Federal assistance. Local governmental agencles should give reasonable assurance that the recreational areas resulting from proposed improvements will be adequately regulated to insure the continuance of the expected benefits throughout the life of the projects. When pollution of adjacent water areas menaces the recreational value of a project, the abatement of this pollution by local agencies should be made a condition of Federal assistance.

As stated above, the law recognizes the element of improvement as well as protection. Nevertheless this law apparently limits Federal assistance to a maximum of one-third of the cost of protective construction. Thus, in the opinion of the writer, improyements which amount substantially to the creation of new beaches, or to the widening of existing beaches beyond the requirements of adequate protective construction, should be undertaken wholly at local expense. Federal participation should be limited to a maximum of one-third of the construction cost of the protective measures needed to stabilize these improved beaches.

One provision of the law authorizing Federal participation in the cost of shore protective works has not as yet been mentioned. This is the so-called "Highway Clause," which authorizes Federal participation in the cost of repalr or replacement of seawalls or similar stmuctures previously built to protect public highways against erosion by waves and ocean currents. This clause is of rather narrow application and is hedged about with restrictions. It will not be discussed in detail here.

The foregoing legislation applies to the continental shore of the United States, including those of the Great Lakes, but does not apply elther to Alaska or to the insular possessions. Consequently, a seeming paradox exists which allows Federal cooperation (including sharing costs) with territorial governments in the preparation of cooperative reports but does not authorize Federal assistance in the actual control of beach erosion. This inconsistency is, however, not important at the present time. Beach erosion control reports originating in our territories will no doubt be considered on their individual merits and Congressional authorization of these projects will include approval of whatever Federal assistance may be recommended in the reports. The present law does not authorize Federal assistance to the territories but on the other hand, it does not bar such assistance.

It $w_{111}$ be recalled that, prior to the end of World War II, the Board restricted its activities largely to the preparation and review of cooperative reports. During that period the fleld work of these reports was done by $10 c a 1$ District Englneers. The reports themselves were, however, written by the Board staff under the supervision of the Board itself. In 1946, the increasing prospective volume of this cooperative work made it appear wise to decentralize to the Districts the preparation of the entire reports. This practice has been followed since that year and is gradually demonstrating its advantages. As was to be expected, practical knowledge of beach erosion control englneering is now being more widely disseminated in the field than was previously the case. In addition, the field agencies are more keenly aware of the intimate relations which exist between navigation improvements and the adjacent shorelines. The function of the Board staff in this connection has gradually changed from that of an operating agency to a supervisory and consultant body.

\section{INVESTIGATION AND RESEARCH}

In retrospect it seems unfortunate that legislative authority to undertake a program of research and general investigation was not received by the Beach Erosion Board before 1945. This delay was probably due to the fact that the original concept of the Board was that of an operating agency rather than an investigative one. This was perhaps inevitable. Nevertheless, the result has been a delay of about one decade in the research program. The war years were not lost by any means. Indeed during those years, marked advances were achieved in our knowledge of beach erosion processes by reason of the military research programs which were under- 
taken as incident to naval and amphibious warfare. Institutions of learning, such as the University of California and Scripps Institution of Oceanography, were very active in carrying out these war programs.

There is nevertheless still a wide field for further investigation. The following random comments are the personal opinions of the writer and are not to be considered as representing Board opinion. They are, however, presented here as they illustrate the existing need for further research from the standpoint of practical coastal engineering.

a. The existing method of estimating the volume of littoral drift by measuring the quantities of sand impounded by jetties and similar structures occasionally produces results completely inconsistent with other observed phenomena. Improved methods for determining the direction and quantity of littoral drift are badly needed.

b. The character and amount of onshore and offshore sand movement, as distinct from littoral drift, are not yet thoroughly understood. In the study of extended reaches of shoreline critical areas have been found to exist where the observed directions and estimated volumes of littoral drift indicate that pronounced erosion (or accretion) should occur. Study of these critical areas, however, fails to reveal the existence of this erosion (or accretion). This leads to the conclusion that unobserved sand movements are acting to maintain an equilibrium.

c. The effect of submarine canyons on the littoral movement of beach material is a subject which merits a considerable amount of investigation.

These comments by no means exhaust this field of speculation. They merely illustrate the present need for further study. The program which the Beach Erosion Board is currently carrying out is now about three years old. It is being carried on by the Board staff in Washington, D.C., and also by contracts with New York University, the University of California, and Scripps Institution of Oceanography. The Board staff maintains a field party in California (based at present at San Diego) which is investigating the nature and extent of sand movements along certain beaches. The results of a somewhat similar study at Long Branch, New Jersey, have been published recently.

It is expected that about two additional years must elapse before results of interest to the practical beach erosion control engineer will begin to emerge from this research program. By that time, the Bulletins and Technical Memoranda published by the Board will be of great value to the individual engineer seeking a practical solution to a field problem. For the present, however, the research program is devoted to the development of fundamental concepts of wave motion, sand movement, etc. This is necessary before the practical solution to individual engineering problems becomes feasible.

\section{CONCLUSIONS}

As a result of twenty years of work, a wlde coverage of our shorelines by individual beach erosion studies has been obtained. This coverage is increasing. As of the date of this writing, sixty elght cooperative reports have been completed, including five now under Board consideration. Eleven additional reports are expected to reach the Board during the current fiscal year and the load during the following fiscal year will probably be equally as heavy. An appreciable volume of additional coverage is obtainable from the discussions of shoreline changes which are contained in current reports on proposed navigation improvements. The current research program is producing a fund of useful data and basic information which will be of ever increasing value as the program develops. From this mass of information, certain concepts as to the characteristics and processes of our major reaches of coastline are gradually developing. The reasons for these concepts and the differences between different coastal regions are slowly becoming apparent. Much remains to be done but there is room for optimism that our knowledge of beach erosion control engineering will make more rapid advances in the near future than at any time in the past. 